\title{
FAMILY MATTERS: BUGIS GENEALOGIES AND THEIR CONTRIBUTION TO AUSTRONESIAN STUDIES
}

\author{
Ian Caldwell \\ School of Languages, Cultures and Societies, \\ University of Leeds, Leeds LS2 9JT, UK \\ email: i.caldwell@leeds.ac.uk \\ Kathryn Wellen ${ }^{* *}$ \\ Royal Netherlands Institute of Southeast Asian and Caribbean Studies, \\ PO Box 9515, 2300RA Leiden, the Netherlands \\ email:wellen@kitlv.nl
}

Published online: 15 September 2016

To cite this article: Caldwell, I. and Wellen, K. 2016. Family matters: Bugis genealogies and their contribution to Austronesian studies. In Orality, writing and history: The literature of the Bugis and Makasar of South Sulawesi, ed. Druce, S. C. International Journal of Asia Pacific Studies 12 (Supp. 1): 119-141, http://dx.doi.org/10.21315/ijaps2016.12.s1.6

To link to this article: http://dx.doi.org/10.21315/ijaps2016.12.s1.6

\begin{abstract}
Early Bugis written sources consist largely of genealogies. Assuming no significant loss of other genres, it is clear that genealogies were central to Bugis historical record keeping. The paper sets out to explain why genealogies were first written down, what purpose they served, and why they were repeatedly added to and copied. It argues that written genealogies had no function as practical documents. Instead, they owed their existence directly to the development of writing around $1400 \mathrm{CE}$, and to the status that their possession conferred on their owners. The article sets out what historians can learn from genealogies of South Sulawesi prior to the arrival of the first Western visitors. It draws attention to a threegeneration myth of origin similar to that found in the Malay Hikayat Banjar, and argues that this myth was central to agricultural fertility, and the right to rule.
\end{abstract}


Keywords: Bugis genealogies, Austronesian history, families in statecraft, myth, Bugis studies

\section{INTRODUCTION $^{1}$}

One of the challenges of studying Austronesian-speaking societies through their own writings is the nature of these texts. In most parts of the Austronesian world where writing systems were developed, the cultural atmosphere was subject from the start to significant foreign influences such as Hinduism and Mahayana Buddhism. For Java and Bali, these cultural influences were so great that their societies were transformed in important ways (Coedès 1968; Bernet Kempers 1978). The earliest Malay inscriptions in an Indic script contain numerous loan words from the Sanskrit, while the earliest inscription in a modified Arabic script praises the prophet of God and God Almighty for the religion of Islam (Casparis 1956; An Ismanto 2009). The first book published in an indigenous language in the Philippines was a catechism, and even the most fervent defenders of Hawaiian language and indigenous knowledge also defended Christianity (Quirino 1973; Silva 2009: 45). Separating out Indic, Islamic and Christian influences is a challenge for scholars who wish to use these sources to describe and analyse the societies that produced them.

Bugis texts from South Sulawesi offer a refreshing reprieve from this problem. While the writing systems of South Sulawesi are Indic-based, its societies were never Indianised. ${ }^{2}$ The development of writing based on an early variety of Gujarati script (Miller 2016) appears to date from well over a century before the first visit by the Portuguese to Sulawesi, and two centuries before local societies formally converted to Islam. ${ }^{3}$ During this period, the Bugis and Makasar ${ }^{4}$ used writing for their own purposes to record what was of interest and importance for their societies. They documented the culture and history of this period from the perspective of an Austronesian-speaking society comparatively free from foreign cultural influences. While no physical archives from the 15th or 16th centuries remain, some works, or fragments of works, were recopied and passed down through the centuries. Here we are concerned only with Bugis written sources, although many of the general features we describe would be applicable also to Makasar sources.

The archaic nature of traditional Bugis literature is obvious in the poetic tradition La Galigo; Macknight (2003) and Koolhof (2004) have described how this mythological epic details the pre-Islamic cosmos and provides insights into Bugis culture. When it comes to political and social 
history, however, some of the best available sources are a class of works that can be categorised as genealogies. ${ }^{5}$ These genealogies record family relationships over multiple generations but differ from the narrow sense of the term genealogy in that their central lines, namely the series of key individuals that determine the inclusion of other members of each generation, follow the transmission of political office rather than a formal rule of kinship, such as primogeniture or matrilineal descent. The holder of political office could be succeeded not only by his or her children, but also by other her relatives. ${ }^{6}$ In short, Bugis genealogies are records of affinal and consanguinal relations among the ruling elites of South Sulawesi's myriad Bugis polities. These polities ranged in size from large territorial groupings, which historians call kingdoms and archaeologists call complex chiefdoms, to smaller tributary chiefdoms allied to and comprising those kingdoms.

While presumably written for the purpose of securing advantages for existing elites and their offspring, Bugis genealogies inadvertently provide a record of an un-Indianised (and before 1605 un-Islamised) Austronesian society. Containing information from as early as $1400 \mathrm{CE}$ and continuing down to the 20th century, genealogies are important resources for the reconstruction of the peninsula's pre-European contact past. As sources for the history of South Sulawesi, genealogies have two great strengths. The first is that they are plentiful, not just as free-standing works but as core elements of other historical genres. The second is that while they are primarily concerned with recording blood and marital relationships among the ruling elite, they outline the political, and to a lesser degree economic, history of the Bugis kingdoms.

Bugis genealogies are of singular importance for the study of Austronesian-speaking societies. South Sulawesi lies in the easternmost region of the Austronesian world in which societies used an indigenous, albeit Indic-based, system of writing to record their pasts. Much of what the Bugis chose to record consisted of genealogies of the peninsula's ruling families, in which one can see the importance of origins and status as claims to power. Because the early sections of Bugis genealogies were written over two centuries prior to the advent of Islam, they provide an exceptionally rare window on to the social and political hierarchy of a non-Indicised, Austronesian-speaking people as well as providing insights into the conceptual universe of Bugis society on the eve of Islamisation and European contact. They also provide evidence of the importance of social precedence in Bugis society. Origins, and the status that they confer on living individuals, are essential components of the founder-focused ideology central to most Austronesian societies. As Bellwood (2006: 28-29) has argued, elements of founder-focused ideologies are so widespread in 
Austronesia that they are likely to be quite ancient, and may have been an important stimulus in the process of Austronesian expansion.

\section{CHARACTERISTICS}

Bugis genealogies are written on European paper in an Indic-derived script and generally form part of a codex, or bound book of European paper. Most codices date from the 19th century; a few are from the late 18th century and some the early 20th century. The largest collection of material is held in the National Archives in Makassar, being microfilmed copies of locally owned codices. Most codices in European collections were copied from private collections in South Sulawesi during the 19th and 20th centuries. Sizable collections are held in the libraries of the University of Leiden and on microfilm in the Australian National University library, while smaller collections can be found in other university and national libraries.

European paper did not become readily available in South Sulawesi until the 18th century, and only a handful of Bugis documents can be dated to this century. Prior to the availability of paper, texts were incised in a single line on long strips of palm leaf that were sewn together end to end and rolled into a spool, sometimes mounted in a wooden frame, rather like a Philips tape cassette. Examples of these spools can be found in museums and libraries and occasionally in private collections (see Macknight 2016). The writer of the 17th-century chronicle of Boné refers to these palm-leaf documents as the "writings which are rolled up" (attoriolong rilullungngé), with the remark that additional genealogical information may be found within them. The limitations imposed by writing on narrow palm leaf strips is reflected in the fact that all Bugis works from the period before the availability of European paper are short; indeed, most can be transcribed upon a single page. It was almost certainly not until the 17th and 18th centuries that longer works such as chronicles were written (Macknight 2000).

Just as the advent of paper is reflected in the length of historical works, so is the advent of writing discernible in the quantity and quality of detail they contain. Caldwell (1988: 171) has argued that the sudden proliferation of historical information provided from approximately 1400 onwards reflects the start of writing in South Sulawesi. The historical information that precedes this quantitative and qualitative expansion of detail is best understood as that which could be recalled from oral tradition at the time when writing was developed. The historical information for the period after c. 1400 is more likely to have been recorded as it occurred, or to 
have been based on historical sources that were written contemporaneously, or shortly after, the events that they describe. An important point here is that the striking expansion of information after 1400 has no relation to the origins of organised political life in South Sulawesi but simply represents the moment when writing began. Several former kingdoms of South Sulawesi have archaeological records that date back to the 13th or 14th centuries (Kallupa et al. 1989; Bulbeck 1992; Bulbeck and Caldwell 2000, 2004; Druce 2009). However, none of the written records of those kingdoms contains reliable information before the 15th century. It is therefore not possible to date the origins of kingdoms by their historical records as the origin of writing postdates the origins of complex society, sometimes by as much as two centuries. ${ }^{7}$ The importance of recognising the chronological limitations of written sources (of which genealogies are perhaps the most ancient) cannot be over emphasised.

The impact of the advent of writing is clearly reflected in genealogies. Most begin with a marriage between a heavenly-descended male (to manurung) and/or a female who arose from the underworld (to tompoq). These archetypal figures are typically followed by the names of two or three rulers about whom little is known. These individuals and the places with which they are associated (where these are provided) are those that presumably were recalled or retained in oral tradition at the moment when writing was developed. Within a couple of generations of these archaic figures, however, comes an abrupt and significant increase in information. Suddenly, a much greater level of detail is provided. This detail may include the names of the ruler's children, whom the children married and where, the political offices they held, lands that they opened, whether their spouses were first, second or third cousins, their teknonyms, posthumous titles, and even occasional nicknames.

Because of the inclusion of non-genealogical information, it is difficult to draw a firm dividing line between the categories, or genres, of king lists, genealogies and chronicles. As Macknight (1984: 109) observes: "The distinction between chronicles and king lists is somewhat artificial, since the chronicles are based on accounts of successive reigns." Arguably, genealogies are a midpoint on a continuum between king lists and chronicles: it is the line of a polity's rulers that provides the narrative structure for all three, the essential differences being the quantity of information provided in addition to the series of rulers. In the remainder of this article we shall use the term genealogy to refer to information found both in free standing genealogies and in narrative works structured around genealogies. 


\section{WRITING AND TRANSMISSION}

As we have noted, Bugis genealogies always follow the line of the rulers of a polity or settlement. Given the paramount importance of status in Bugis society, polities of any significant size were always ruled by high status individuals. Social status in Bugis society is largely ascriptive, meaning that is it is passed from one generation to another by birth. This status is held to have originated from the to manurung and to tompoq, who begin the genealogies of most major and minor kingdoms of South Sulawesi. ${ }^{8}$ To manurung, who are male, descend from the upper world along a rainbow, emerge from a bamboo segment, or appear, mysteriously, on top of a hill. To tompoq, who are female, arise from the underworld, borne by the sea or river foam. ${ }^{9}$ The idea of divine beings appearing from the sky or from the sea or river reflects a pre-Indic, pre-Islamic conception of the universe as comprising a seven-tiered upper world of the gods, the world of Man, and an underworld of seven layers, ruled also by gods. ${ }^{10}$ The necessity for rulers to be descended from to manurung and to tompoq limited eligibility for high political office to members of an elite kinship group that could claim such a status. ${ }^{11}$ Demonstrating ascriptive status, and documenting the social advantage that resulted from this status, were therefore the main functions of genealogies. ${ }^{12}$ Possession of a genealogy was in itself a claim to high status, and the possibility of political office. There are no written genealogies of commoners. ${ }^{13}$

Despite the importance of ascriptive status among the Bugis, it is possible for a man to raise his social standing through achievement, especially if he is already a member of this ascriptive elite. ${ }^{14}$ One especially respected achievement was the opening of new lands and consequent enrichment (and still is: see Acciaioli 2009). Many genealogies record this process with the words ia timpangngni, "he/she opened," followed by the name of a settlement, such an act of foundation being a source of status for the founder's descendants. While there exists no first-person statements of intent, it would seem that genealogies were committed to writing in order to create a record of status and the right to rule as arung (lord). This right could be claimed on the basis of divine ancestry, the founding of a settlement, or both. In that genealogies record this information, they are a mechanism of what Bellwood (2006: 29) has called "founder-rank enhancement" as well as a record, through the genealogies' central lines of rulers, of this principle in action.

Bugis genealogies comprise largely untapped sources of information on South Sulawesi's past. Some, primarily those found in chronicles, have been used to write the histories of the larger kingdoms (Zainal Abidin 1985; 
Bulbeck 1996; Druce 2009), but most remain unexamined in the scattered codices of Bugis historical writings. These texts were copied and recopied over time, leading to corruption, with the result that different versions of a genealogy may offer variant names and places. However, the generational structure remains essentially unchanged, and all but the most fragmentary texts display sufficient coherence to allow meaningful comparison with other versions of what is clearly a single tradition. Occasionally, individuals or marriages appear in the genealogies of more than one polity, which enables a degree of cross-checking. Larger genealogies may contain an event such as the signing of a treaty, or the date of the conversion of a ruler to Islam, which provides a further measure of consistency. Before historical enquiry can be made of any genealogy, it is therefore necessary to collect all known versions and to make a careful philological examination of their history and relationship. ${ }^{15} \mathrm{~A}$ base text can then be chosen and considered against other texts, and against the relationship between texts. As most historians are not trained philologists and the work is time consuming, it is hardly surprising that genealogies are a neglected source in historical writing on South Sulawesi.

Using such texts also requires careful research into their chronologies, as Bugis genealogies do not contain dates for the period before 1600 . Chronicles may provide reign lengths for some rulers, but none does for all. It is therefore necessary to develop a standard reign length for each genealogy in order to fill in the gaps. A starting point is the formal conversion to Islam of the rulers of South Sulawesi's major kingdoms between 1605 and 1611. The date of conversion for each kingdom is known and provides a secure date for backdating rulers. By using known and estimated reign lengths, and applying cross-checks with other genealogies, it is possible to date the earliest named rulers to the 14 th or 15 th century. ${ }^{16}$ However, Caldwell (1988: 171) has provided evidence that writing was first developed around 1400, and warned that claims that appear older than this should be treated with caution. This is because any information predating c. 1400 is drawn from oral history or oral tradition current at the time of composition of the work in which it is found (c.f. Vansina 1985). Two examples, taken from the royal genealogy of Cina and the royal genealogy of Soppéng (Caldwell 1988), illustrate these general points.

The royal genealogy of Cina provides scant information about its first four rulers, three of whom appear in legends concerned with the kingdom of Luwuq. The fourth ruler, La Sengngeng and his wife, Wé Mata Timoq, can be backdated to the early 14th century; arguably these are names celebrated in oral tradition perhaps a century or so later when the genealogy was composed. It is only with the fifth ruler, La Patauq that one starts to feel on 
firmer historical ground. All the Cina genealogy tells us, however, is that La Patauq married Wé Tenriwéwang and fathered three children, La Pottoanging, La Pasangkadi and La Padasajati, who ruled respectively at Wawolonrong, Pammana and Tétéwatu. These three brothers can be backdated to the late 14th century and head what are effectively three related genealogies. ${ }^{17}$ It is with the descendants of La Pasangkadi that the genealogy is primarily concerned. It tells us whom and where they married, the lands that they opened, as well as the names of, and information on, affinal and cosanguinal kin.

The royal genealogy of Soppéng likewise provides little information regarding its first three rulers. It tells us that the first ruler descended from the upperworld at Sékkanyiliq (in north Soppéng) and married in Suppaq, and the names of his wife and son, the second ruler. Of the latter we are told the name of his wife and two children, and that they ruled at Suppaq and at West Soppéng. Of the third ruler, we are told simply of his marriage at Balubu, on the west coast, south of Suppaq, and the names of his wife and daughter, the fourth ruler of Soppéng. It is only upon mention of this daughter, Wé Tékéwanua, who can be dated to the early 15 th century, that there is a sudden expansion of detail. Wé Tékéwanua is among the first, convincingly real individuals in Bugis historiography. She is recorded as having been a powerful ruler who expanded agriculture, resettled villages, and who married her sons and daughters to the offspring of influential families:

Wé Tékéwanua was Datu of West Soppéng. She ruled at Suppaq. She broke the broad and split the long. She planted sugarcane and ants swarmed. She looked down at the lake: she summoned the people of Sidénréng. She looked down at the lake: she summoned the people of Népo [to come like the] turtledoves. [She] looked down at the lake: she summoned the people of Marioriawa. [She] looked down at the lake, and they settled together with the people of Népo. Wé Tékéwanua was young. She was Datu of Suppaq. Wé Tékéwanua married at Léworeng with La Temmapéoq. They had seven children, [among them] La Wadeng, who ruled Bila; he was the first Mangépa of Soppéng. The younger brother of La Wadeng, called La Makkanengnga, was Datu of West Soppéng. Their [other] children were La Dumola, La Tubé, Wé Baku and [Wé] Tenritabireng. 
This extract provides no less than 20 discrete pieces of information about Wé Tékéwanua; for the preceding three rulers, excluding their names, we are given a total of just nine. Genealogies from Suppaq, Sidénréng, Soppéng, Boné and Luwuq tell a similar story (Caldwell 1988; Druce 2009; Macknight and Mukhlis, unpublished). These qualitative and quantitative expansions of data reflect the development of writing. The names that continue the royal genealogy of Soppéng after c.1400 are likely to have been recorded incrementally, generation by generation, as opposed to recorded simultaneously as those from memory or oral tradition would have been at the time that writing was developed. ${ }^{18}$ In short, Bugis genealogies, which we have argued contain contemporary information from the 15th century onwards, contain little reliable information before c. 1400 .

\section{DIVINE ORIGINS}

As previously described, most Bugis genealogies begin with a to manurung or to manurung to tompoq couple (and in at least one instance a single to tompoq). These divine beings provide a special status to their earthly descendants and implicitly accord them the right to rule. These divine marriages are strikingly similar in structure to a genealogy that J. J. Ras in Hikajat Bandjar (1968) has termed the "Malay Myth of Origin." We suspect that both are expressions of a broader tradition that underlies both sets of sources. Ras draws attention to a widespread myth of a marriage between a female who arises out of the water foam and a local prince, found in various Malay, Javanese and Dayak sources. He writes (Ras: 94): "This representation of the royal dynasty as arising from a union of opposite cosmic elements [...] obviously represents a primitive Indonesian cosmological dualism." He adds that: "As well as a princess emerging from the water, we find in several [...] narratives a princess emerging from a bamboo. [...] In the Hikayat Marong Mahawangsa it is a prince, not a princess, and he is married to the princess who has emerged from the foam." Ras argues that:

The marriage between the ancestor and ancestress of the royal dynasty depicted in the myth unmistakably symbolizes a union between the two cosmic elements of the waters (the nether world) and the sun (heaven). This mythical marriage constitutes the beginning of the dynasty and, by extension, also forms the beginning of the (history of the) community ruled by 
descendants of the first royal couple. (Ras: 94, emphasis in original.)

In some versions of the myth we find a subsequent marriage between the son of the first divine union and a second divine female:

Prince descending from the sky $=$ princess emerging from the water of local river
\[ \text { son }=\text { princess emerging from bamboo } \]

(Ras 1968: 95)

Ras' treatment of the myth reflects his interest in ancient Indonesian religious beliefs, classificatory divisions, and the relations of these to moieties or descent groups. Here we are concerned only with the essential structure of the myth. Ras' sources raise puzzling questions, such as why the son of the first divine union marries a second princess who emerges from the water foam, and why both males and females are found inside bamboo segments. These questions can be addressed through a comparison of Ras' Malay Myth of Origin and origin stories contained in Bugis genealogies. A useful example is the origin myth of the ruling family of Luwuq (Caldwell 1988: 62-64), which is set out below.

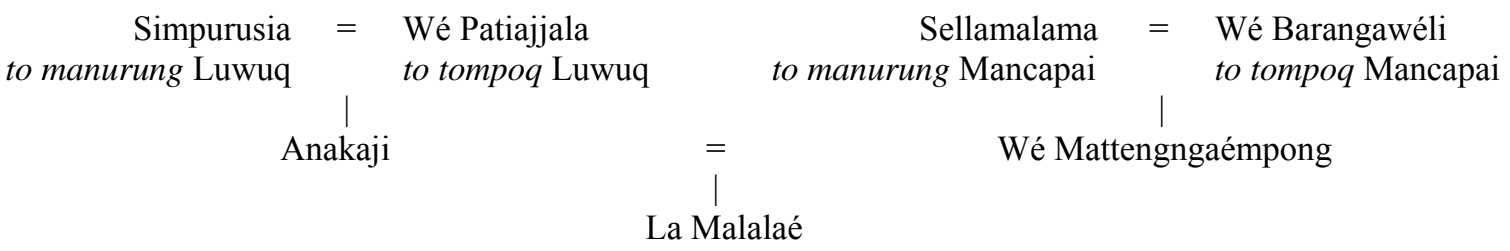

We would argue that the Malay Myth of Origin's "prince descending from heaven" and "princess arising from the water of local river" occupy the same structural position as Simpurusia and Wé Patiajjala in the Luwuq genealogy. Their son, Anakaji, is equivalent to the son in the Malay Myth of Origin. In order to produce an heir who is fully of this world yet is of undiluted, divine ancestry, Anakaji must marry a female of equivalent status; or as the Bugis would express it, has pure white blood. But instead of marrying a princess emerging from a bamboo he marries the daughter of the to manurung and to tompoq of Mancapai. It is appropriate that her name, Wé Mattengngaémpong, means "She who arose in the middle of the waves," the structural equivalent of the "princess emerging from bamboo." Bugis and Malay myths suggest that from a cosmological perspective bamboo is a 
plant both of the earth and the sky, because it conveys divine beings from both realms. ${ }^{19}$

This three-generation myth of origin can be reduced to a single upper and lower world couple (as we see in the Malay Myth of Origin, and in Bugis sources), whose son or daughter may start a "historical" genealogy. In Malay versions of the myth, a daughter may marry a wandering foreign prince; the couple then completes the myth with the birth of a son or daughter. ${ }^{20}$ In Chapter Four of Hikajat Bandjar, Ras sets out the origin stories of ruling families of various Malay and Javanese polities and concludes that these are local variants of a proto-story (Ras: 91). We believe that the genealogical core of this proto-story can be expressed by the below model:

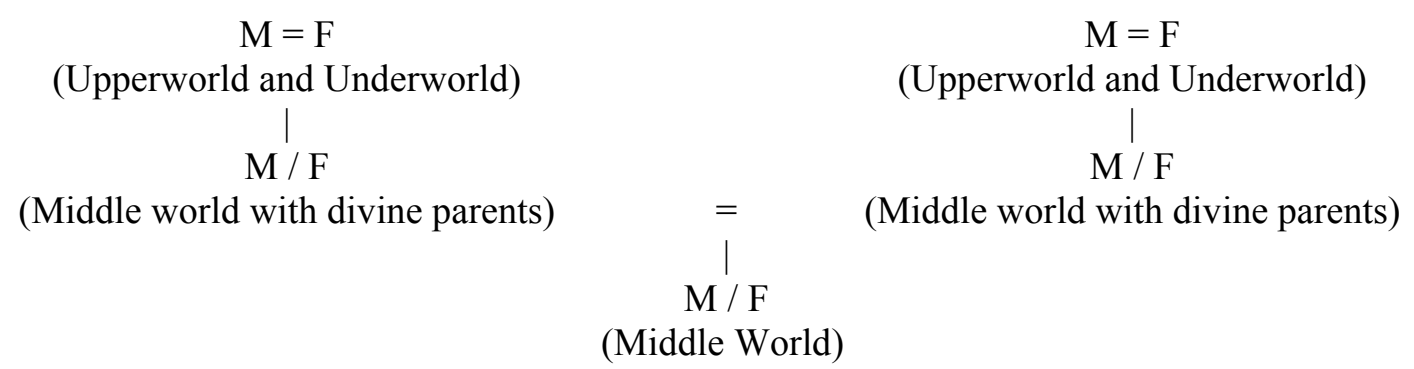

Devoid of its narrative decoration, the origin story of the ruling elite in the Salasilah Kutai fits this model perfectly. ${ }^{21}$

\section{KEEPING IT IN THE FAMILY}

It is clear from Bugis genealogies that the rulers of the myriad small and large kingdoms of South Sulawesi were no strangers to each other. Quite the opposite: they were bound to one another through an extended network of affinal and consanguinal relationships. The nobility in South Sulawesi were concerned primarily with a potential marriage partner's status, but this concern did not preclude the strategic value of a proposed union (c.f. Bulbeck 1996). Marriages are recorded between high-ranking individuals from different polities, and even from different ethnic groups. Indeed, it has even been suggested that such marriages and the alliances that they created have effectively transformed South Sulawesi's ruling families into a single, peninsula-wide elite (Acciaioli 2009: 76).

An excellent example of how closely 16th-century rulers were related is provided by the genealogies of two Ajattappareng kingdoms, Suppaq and Sawitto (Druce 2009: Figures 4.1, 4.2). These record how La Botillangiq, an 
early 16th century ruler of Tanétélangiq, married twice, firstly with the arung of Balusu and secondly with the arung of Marioriwawo. His daughter from his second marriage, Wé Tappatana, also married twice, firstly with the addaoang of Sidénréng, La Pasampoi, and secondly with the datu of Suppaq, La Putébulu. La Patéddungi, Wé Tappatana's son by La Pasampoi, succeeded his father as addaoang of Sidénréng, while another son from this marriage became ruler of Bulucénrana. ${ }^{22}$ Makarié, Wé Tappatana's son by her marriage with La Putébulu, succeeded his father as ruler of Suppaq. ${ }^{23}$ Thus the ruler of Sidénréng was the half-brother of the ruler of Suppaq, and both were grandsons of the arung Marioriwawo and Tanétélangiq. La Patéddungi married the sister of the arung Rappang and thus became the brother-in-law of her husband the ruler of Sawitto. Makkarié was the halfbrother of La Palétéang, the ruler of Sawitto: he married the arung Loa, and through his father was related to the arung of Parangki, Bojo, Palanro and Népo. Thus Wé Tappatana's sons could claim family relationships with no fewer than twelve ruling families in the region west of the lakes.

Through strategic marriages it seems to have been possible to make a claim to rule at more than one polity. La Pancai, a late 16th century noble, is recorded as having been ruler both of Suppaq and Sawitto. His father had been ruler of Sawitto and his mother was the daughter of Makkarié the ruler of Suppaq. These two arung-ships were then passed on to his daughter Wé Passulé. In the 18th century, Sultan Ahmad as-Saleh of Boné (1775-1812) laid claim to the throne of Gowa on the grounds that he was the greatgrandson of Sultan Ismail of Gowa (1709-1711) who had later been ruler of Boné (Omar 2003: 58).

To point to the close relationships between members of the Bugis ruling elite is not to say that relations between them were always harmonious. In particular, the theme of disagreements between brothers is common in Bugis historiography. La Bottilangiq, the father of Wé Tappatana (above), is said to have left Tanétélangiq for Balusu after his siblings made war against him:

This story tells of our lord La Bottilangiq, at the time that he was angry and left for Marioriwawo, taking his sadness with him. [This was] because his siblings made war against him. He left with his people, there were as many as eight hundred people. Each took their possessions and swords adorned with gold. He stopped in Balusu and married the arung of Balusu (Druce 2009: $75)$. 
The "chronicle" of Sidénréng describes the founding of the kingdom by eight sons of the ruler of Sangallaq in Tana Toraja, whose elder brother, having succeeded his father, drove them out of their homeland:

There was an arung in Tanatoraja called La Maddaremmeng, the son of the arung of Sangallaq [...] Now La Maddaremmeng oppressed his brothers in Tanatoraja, he fought with his eight brothers in Tanatoraja. The eight brothers were saddened, so they decided to leave Tanatoraja and go down to the plain to look for a place to live (Caldwell 1988: 144).

Wajorese texts relate how La Banraq, one of the younger sons of the Datu of Soppéng, inherited a small parcel of forested land. He and his foster father made it so prosperous that when famine struck Soppéng they were able to provide for the community. But his jealous older brothers plotted against him:

The brothers of La Banraq came together. They said "We want to order him to leave. If he stays here, he will draw the datuship of Soppéng to himself." His seven brothers decided to order him to go away. They sent a messenger to La Banraq. The messenger said "Go away, Banraq. Leave Soppéng. You're planning to take over Soppéng." La Banraq said "Let us go, father." His father agreed. After these words La Banraq left (H1514, folder 6, La Banraq stories no.5).

Another recurrent and often related motif in genealogies is the opening of new lands. The founding to manurung of the royal genealogy of Cina is recorded as having opened Talettu, a settlement near Séngkang. La Panyorongi, an early 16th-century ruler of Cina is recorded as having opened Amali in kabupaten Boné) and Baringeng (kabupaten Soppéng). The early 14th-century ruler of Soppéng, Wé Tékkéwanua, previously mentioned as one of the first identifiable historical individual in Bugis sources, is recorded as having summoned people from Népo and Marioriawa in order to settle them on the shores of Lake Témpé. In the Chronicle of Boné, the early 16th-century ruler Wé Benrigauq is recorded as having acquired a hill in Boné in exchange for ninety buffalo bulls. She ordered people to settle at the hill and to lay out gardens; later she bought a hill south of Laliddoq for thirty buffalos. In the Wajorese chronicles, La Banraq, having been driven away from Soppéng by his brothers, cultivated a forest granted him by the ruler of Akkotengngeng. Finding his new ruler 
overbearing, he offered his services to La Patiroi, the ruler of Cinnottabiq. Settling in Wajoq, he cultivated land and assisted the local population during a famine; later he founded a settlement called Bajo (Noorduyn 1955: $35)$.

Bugis genealogies record how migrants such as La Banraq benefitted from what Bellwood calls "founder rank enhancement" which he defines as "a process whereby junior founders moving into relative or absolute isolation (such as a new island, previously inhabited or not) could establish senior lines, aggrandise their resources, and attempt to ensure methods of genealogical inheritance which would retain privileges for their descendants" (Bellwood 2006: 20). These stories provide evidence for ways in which family disputes could inspire the opening of new settlements. With their dialogues and their expressions of emotions such as jealousy and sadness, they bring a human dimension to the sparse records of the 15th and 16 th centuries.

\section{BINDING KINGDOMS}

We have argued that the primary purpose of Bugis genealogies was to document the descent of elites from heavenly ancestors or glorified community founders, to accord privileges to the ruling elite on the basis of this descent, and to transfer the advantages that this elite enjoyed to a following generation. In the process of documenting family relationships for these purposes, a substantial body of historical information about politics and families was inadvertently created. This is an under-used source for the writing of South Sulawesi's history.

One notable feature of these records is the manner in which marriage was strategically used to bind kingdoms together. There were other methods of binding kingdoms, such as treaties and conquest, but marriage was in all likelihood cheaper than warfare. And it was relatively enduring. David Bulbeck's research has revealed that among the Makasars, alliances established through marriage generally lasted longer than did alliances established through treaty (Bulbeck 1992: 121).

If genealogical information in the chronicles of Wajoq and Boné is examined closely, a number of correlations between marriage and state formation by voluntary and compulsory means of incorporation become apparent. According to the Wajorese chronicles, of 40 communities or small polities that joined Wajoq, 25 were conquered and 15 joined voluntarily. Marriages are associated in the chronicles with the incorporation of these settlements, but only rarely is it explicitly stated whether marriage occurred 
before or after incorporation. However, marriage is 70 percent more common in the case of voluntary association than in the case of conquest. Statistics extracted from the chronicle of Boné also show a much smaller number of marriages associated with settlements incorporated by conquest than for settlements incorporated by voluntary association.

The chronicle of Boné also records significantly fewer marriages than does the chronicle of Wajoq. While the chronicle of Boné is a much shorter work, it would nevertheless appear that strategic marriage played a greater role in the expansion and consolidation of Wajoq than it did in Boné. This may be attributable to differences in the political culture of the two states. Wajoq was a federation: it had three main sub-polities known as limpo, each with its own administration and customs, and each sub-polity was composed of four smaller constituents. In this context marriage may have been considered a political tool to be used alongside envoys, representative councils and compulsory contributions to government projects as a means of consolidating and maintaining the unity of the federation. While marriages with polities outside Wajoq are mentioned, the majority of marriages recorded in the chronicle were between different parts of Wajoq. Another possible explanation for the greater importance of marriage as a tool of consolidation is simply that settlements which joined Wajoq voluntarily were already to some extent incorporated into a web of kinship relations similar to those described above in the royal genealogies of Suppaq and Sawitto.

Politics in Boné differed substantially, in that war seems to have played a larger role in the formation of the kingdom: according its chronicle, two-thirds of Boné's tributaries were incorporated by force. While undoubtedly a reflection of different historical circumstances and personalities, this difference presumably stemmed in part from geography. While Wajoq has a landscape of arable lands interspersed with hilly terrains and marshes, Boné consists largely of a large, contiguous plain that facilitated the consolidation of territory. The emphasis on conquest in the chronicle of Boné reflects in particular the rapid expansion of the kingdom under its mid- to late 15th-century ruler Kerrampéluaq. During his 72 -year reign, no fewer than 17 lands were conquered; other lands joined Boné voluntarily, or at least were said to do so.

Marriage could be a tool for reconciliation as well as for expansion and consolidation. The Lontaraq Sukkuqna Wajoq (Zainal Abidin 1985) offers a clear example of this strategy in use in the 18th century. During the reign of Arung Matoa La Maddukelleng (1736-1754) there were numerous conflicts between different factions in Wajoq. One conflict was between La Maddukelleng and his former ally La Gauq, who sought control over 
Sidénréng, then a vassal of Wajoq. Accused of undermining La Maddukelleng, La Gauq sought pardon, but La Maddukelleng was implacable. As a last resort, La Gauq arranged a marriage between his own brother-in-law and the sister of Arung Bénténg, a close ally of La Maddukelleng. The proposal was well received and after the marriage celebrations the relationship between La Gauq and La Maddukelleng improved. Ultimately, however, the agreement was insufficient for resolving the conflict, which ended only with the death of La Gauq and the resignation of La Maddukelleng during an attack on Sidénréng (Salim 1985).

An earlier episode from the career of La Maddukelleng also indicates that strategic marriages were an important part of Bugis statecraft overseas. Upon his departure from Wajoq, La Maddukelleng is recorded as having said "My assets are three: the skill of my tongue, the point of my weapon, and the tip of my penis" (LSW f.231.). These are references to diplomacy, military prowess and marriage. La Maddukelleng is known to have married the daughter of the ruler of Pasir on the east coast of Kalimantan, where he settled after leaving Wajoq. Subsequently he used a combination of diplomacy and force to acquire the leadership of Pasir. ${ }^{24}$

\section{BUGIS GENEALOGIES IN THE AUSTRONESIAN CONTEXT}

As previously argued, Bugis genealogies constitute a rare window on to the conceptual universe of a non-Indicised Austronesian world. For two centuries from about 1400 to 1600 the Bugis wrote about things that concerned them, rather than about foreign ideas that they believed should concern them. These concerns were classic Austronesian ones, such as status, precedence and origins. The use of the word appongenna ("his descendants") in a genealogy to introduce the children and grandchildren of an early 16th century ruler of Luwuq (Caldwell 1988: 70) illustrates this point perfectly. The root of appongenna is pong meaning "tree" or "trunk"; pong is also used to mean "most," indicating a level of superiority. The metaphor of trunks as origins is prevalent in other Austronesian societies (Fox 1996: 6). Among the Meto-speaking communities of West Timor, for example, social relationships are often expressed in terms of trunks and tips. In that a trunk comes before branches both spatially and temporally, the metaphor is an assertion of political and social seniority (McWilliam 2009: 114). Among the Iban of southwestern Borneo, discourse about precedence often focuses on the word pun, meaning trunk, and figuratively meaning origin or cause. In the case of the Iban, the word pun can refer to the 
initiator of community action; it also implies continuity and succession (Sather 1996: 84).

Written without concern for Islamic ideas of leadership or Indian ideas of cosmic authority, Bugis genealogies provide important insights into Austronesian principles and practices of rulership during the 15th and 16th centuries. Among the Bugis, political leadership above the level of headman was restricted to those who could claim descent from divine ancestors, in the form of a hereditary elite (arung) that claimed contested degrees of "white blood," or ascriptive status. It was believed that only those with divine ancestors could ensure prosperity through the intercession of their upperworld and underworld relatives, which ordinary Bugis (to maéga) could not. This organising principle of between ascriptive status and agricultural fertility is explicitly expressed in Bugis writings. A clear expression of this principle is found in the chronicle of Tanété:

There was no arung at Agannionjo. So Puang Lolo [the district chief of Ujung] was chosen to rule; he called himself arung; thus did the people install him as Datu Gollaé ["the sweet lord," the title of the ruler of Tanété] to rule at Agannionjo. He had ruled for a year when the paddy began to die and the number of fish started to decline. After three years the paddy failed completely and the fish disappeared, and the people suffered greatly from starvation. [Puang Lolo] said to the elders, "I am sorry for what I have done. [Go and] fetch an arung to replace me as ruler, for I am not truly the descendant of an arung" (Niemann 1883: 14).

Expressed succinctly, the right to rule was founded upon the possession of divine relatives who could ensure the prosperity of a polity. This is the inherent claim of Bugis genealogies.

At the outset of this article we explained how Bugis genealogies differ from standard genealogies in that their central lines are shaped by the succession of rulers of a polity rather than the descent line of a particular family, Bugis genealogies trace a succession of rulers appointed from an ascriptive elite by related members of this same elite. The appointment to political office was in effect a recognition of status, and failure to achieve office could lead to a decline in status. The conversion of status into power in order secure the status of one's descendants was thus of perpetual concern to the Bugis elite. This helps explain the frequency with which a ruler's brothers migrated in order to found new settlements, for which they would form the apex of a new elite, a highly desirable position in a society with a founder-focused ideology. ${ }^{25}$ This important principle, so clearly evident in 
Bugis genealogies, may have constituted a primary motivation for the opening of new settlements among the Bugis and other Austronesians.

\section{ENDNOTES}

* Ian Caldwell is associate professor of Southeast Asian studies at the University of Leeds. His primary interest is the early history of South Sulawesi; he is the coordinator for the Origin of Complex Society in South Sulawesi (OXIS) research group.

** Kathryn Wellen is senior researcher at the Royal Netherlands Institute of Southeast Asian and Caribbean Studies. Her main research interest is Bugis overseas history.

1 We would like to thank James J. Fox, Campbell Macknight and Sirtjo Koolhof for their helpful criticisms of an earlier draft of this paper. The arguments and evidence presented here are our responsibility alone.

2 Coedès (1968: 15-16) defines Indianisation as the expansion of an organised culture founded on the Indian conception of royalty, Hindu or Buddhist cults, Indian mythology and law, expressed in the Sanskrit language. There was never any knowledge of Sanskrit in South Sulawesi; loan words of Indic origin in South Sulawesi languages were often acquired third or fourth hand through Javanese, Malay and other Austronesian languages (Gonda 1952: 38). This accounts for the occasional use of Javanese-Sanskrit titles in Bugis historical sources.

3 The rulers of the major Bugis kingdoms formally converted to Islam between 1605 and 1611. A handful of Portuguese traders and adventurers visited the west coast of South Sulawesi between 1542 and 1547 (Pelras 1981: 155) but did not establish a permanent presence before the 17th century. The Dutch built a factory in Makassar in 1607 which they abandoned in 1618; they returned in the mid-17th century and conquered the Makasar kingdom of Gowa-Talloq (Encyclopaedie van NederlanschIndië vol. II: 645).

4 Makasar (with one "s") refers to the ethnic group of that name; Makassar is the modern spelling of the capital of South Sulawesi.

5 Genealogies can sometimes be identified by the use of a protective introductory formula "may I not swell [or weaken] for setting out the descendants of the lord X." This formula alerts the reader to the fact that the text is a genealogy. Others begin more prosaically with statements such as "Here is the history of X's descendants," "This sets out the descendants of ruler X" or simply "The ruler called X."

6 In Bugis genealogies the relationship of individuals to the central line of rulers rarely extends further than that of third cousin.

7 No archaeological data is available for the kingdom of Boné.

8 Rarely, a prince or princess from another kingdom may start a genealogy.

9 While common in Malay sources, the motif of a princess being discovered in a bamboo segment is unusual in South Sulawesi. The only occurrence known to the authors is the discovery of the mysterious Banrimanurung by the son of the ruler of Tanatoa in Jeneponto (Caldwell and Bougas 2004: 481).

10 In some texts the upper and underworlds comprise nine layers. 
11 Friedericy (1933: 582) proposed a division of Bugis and Makasar society into two classes: the nobility and the people. This division is accounted for among the Bugis and Makasar by the divine origin of the nobility.

12 As a group, genealogies present a history of the marriage alliances of the ruling elite. They are not, however, intended for the purpose of facilitating matchmaking. Millar (1989) makes no mention of the use of written genealogies in her study of Bugis weddings.

13 See Errington (1989: 219-226) on the restricted knowledge of kin among commoners in kabupaten (regency) Luwu.

${ }^{14}$ This is less true for a woman, whose status is largely determined by that of her parents, and thus acts as a marker of her family's standing.

15 "Voor een beschrijving van de geschiedenis van Z. W. Celebes is een philologisch en historisch-critisch onderzoek van de producten der Makasaarse an Buginese historiografie onontbeerlijk" (Noorduyn 1955: Stellingen).

16 Standard estimated reign lengths vary from between 15 years for Wajoq, which was located in a region of scattered arable lands interspersed with low hills and swamp, to just over 25 years for Boné, which lay on a plain that facilitated territorial consolidation. See http://www.oxis.org/resources-3/pre-islamic-chronologies/index. html regarding the problem of backdating. For a working set of chronologies of the major Bugis kingdoms see http://www.oxis.org/resources-3/pre-islamic-chronologies/ index.html.

17 See Bugis and Makasar manuscript collection of the Nederlands Bijbelgenootschap (Dutch Bible Society), University of Leiden Library (shortened as NBG) 99: 241245; old catalogue of the Bugis and Makasar manuscript collection of the Yayasan Kebudayaan Sulawesi Selatan dan Tenggara, Ujung Pandang (shortened as MAK) 124: 144-247; MAK 223: 142; Salim 1985: 101-105.

18 Errors accumulated by repeated copying account for the greater corruption in older sections of the genealogies.

19 As noted above, in the Hikayat Marong Mahawangsa it is a prince who emerges from a bamboo and who marries a princess who emerges from the foam. In the Hikajat Raja Pasai, a princess from the river is married to a boy found near (but not in) a river (Ras 1968: 88). The royal genealogy of Luwuq describes Simpurusia as having "descended in a bamboo" (Caldwell 1988: 62).

20 In a different version of the Bugis origin myth, the to manurung and to tompoq of Luwuq have a daughter, Wé Jangkawanua, who marries the son of the ruler of Mancapai (Caldwell 1988: 92). This indifference to gender is in keeping with Millar's observation that in South Sulawesi status is more important than gender (Millar 1989).

21 Ras (1968: 93) states: "it is reasonable to consider the story of Puteri Djundjung Buih in the Salasilah Kutai as the one which most faithfully reflects the proto-story from which the narratives in all the Malay texts are assumed to derive." Ottino (1982: 224, 229) also sees parallels between Malagasy myths of origin and Ras' Malay Myth of Origin.

22 Bugis rulers above the rank of matoa (headman) had the title arung (lord); arung of large polities or confederations were sometimes called datu and the pre-Islamic rulers of Sidénréng addaoang. 
${ }^{23}$ La Putébulu (The white-bearded lord) was presumably the ruler visited in 1544 by the Portuguese adventurer Antonio Paiva, who described him as being about 70 years old and one of the most warlike rulers of the west coast (Baker 2005: 63).

${ }^{24}$ On family relations in the Wajorese diaspora, see Wellen (2014), especially chapter five.

25 The claiming of divine descent and the founding of new settlements were related practices, in that they served a similar purpose of establishing status and legitimacy.

\section{BIBLIOGRAPHY}

Acciaioli, G. 2009. Distinguishing hierarchy and precedence: Comparing status distinctions in South Asia and the Austronesian world, with special reference to South Sulawesi. In Precedence: Social differentiation in the Austronesian world, ed. Vischer, M. P., 51-90. Canberra: Australian National University Press.

An Ismanto. 2009. Terengganu stone tablet. Melayu Online. http://melayuonline.com/eng/history/dig/437/terengganu-stone-tablet (accessed 25 June 2015).

Baker, B. 2005. South Sulawesi in 1544: A Portuguese letter. Review of Indonesian and Malaysian Affairs 39 (1): 61-85.

Bellwood, P. 2006. Hierarchy, founder ideology and Austronesian expansion. In Origins, ancestry and alliance: Explorations in Austronesian ethnography, eds. Fox, J. J. and Sather, C., 19-42. Canberra: ANU E Press.

Bernet Kempers, A. J. 1978. Monumental Bali. The Hague: Van Goor.

Bulbeck, F. D. 1992. A tale of two kingdoms: The historical archaeology of Gowa and Tallok, South Sulawesi, Indonesia. PhD diss., Australian National University, Canberra.

. 1996. The politics of marriage and the marriage of polities in Gowa, South Sulawesi, during the 16th and 17th Centuries. In Origins, ancestry and alliance: Explorations in Austronesian ethnography, eds. Fox, J. J. and Sather, C., 283-317. Canberra: ANU E Press.

Bulbeck, D. and Caldwell, I. 2000. Land of iron: The historical archaeology of Luwu and the Cenrana Valley: Results of the origin of complex society in South Sulawesi Project (OXIS). Hull: Centre for South-East Asian Studies, University of Hull.

. 2004. Oryza sativa and the origins of kingdoms in South Sulawesi, Indonesia: Evidence from rice phytoliths. Indonesia and the Malay World 36 (104): 1-20.

Caldwell, I. A. 1988. South Sulawesi A. D. 1300-1600: Ten Bugis texts. PhD diss., Australian National University, Canberra. Available at: http://www.oxis.org/theses/caldwell-1988.pdf. 
1995. Power, state and society among the pre-Islamic Bugis. Bijdragen tot de Taal-, Land- en Volkenkunde 151 (3): 394-421.

Caldwell, I. and Bougas, W. 2004. The early history of Binamu and Bangkala, South Sulawesi. Bijdragen tot de Taal-, Land- en Volkenkunde 164 (4): 456-510.

Casparis, J. G. de. 1956. Selected inscriptions from the 7th to the 9th Century A.D. Bandung: Misa Baru.

Coedès, G. 1968. The Indianized states of Southeast Asia. Canberra: ANU Press.

Druce, S. C. 2009. The lands west of the lakes: A history of the Ajattappareng kingdoms of South Sulawesi, 1200 to 1600 CE. Leiden: KITLV Press.

Encyclopaedie van Nederlandsch-Indië, 2nd ed. 1917. 's-Gravenhage: M. Nijhoff and Leiden: E. J. Brill.

Errington, S. 1989. Meaning and power in a Southeast Asian realm. Princeton, New Jersey: Princeton University Press.

Friedericy, H. J. 1933. De standen bij de Boegineezen en Makassaren. Bijdragen tot de Taal-, Land- en Volkenkunde 90 (1): 447-602.

Fox, J. J. 1996. Introduction. In Origins, ancestry and alliance explorations in Austronesian ethnography, eds. Fox, J. J. and Sather, C., 1-18. Canberra: ANU Press.

Gonda, J. 1952. Sanskrit in Indonesia. Nagpur: International Academy of Indian Culture.

Kallupa, B. et al. 1989. Survey pusat kerajaan Soppeng 1100-1986. Final report to the Australian Myer Foundation, Canberra. Available at http://www.oxis.org/books/soppeng-1986.pdf (accessed 15 December 2014).

Koolhof, S. 2004. The sleeping giant: Dynamics of a Bugis epic (South Sulawesi, Indonesia). In Epic adventures: Heroic narrative in the oral performance traditions of four continents, eds. Jansen, J. and Maier, H. M. J., 98-111. Münster: Lit Verlag.

Macknight, C. C. 1984. The concept of a "work" in Bugis manuscripts. Review of Malaysian and Indonesian Affairs 18: 103-112. . 2000. South Sulawesi chronicles and their possible models. In Vasco da Gama and the linking of Europe and Asia, eds. Disney, A. and Booth, E., 322-332. Oxford and New York: Oxford University Press.

. 2003. La Galigo in comparative perspective. In La Galigo: Menelusuri jejak warisan sastra dunia, eds. Rahman, N., Hukma, A. and Anwar, I., 349-372. Makassar: Pusat Studi La Galigo, Universitas Hasanuddin.

. 2016. The media of Bugis literacy: A coda to Pelras. In Orality, writing and history: The literature of the Bugis and Makasar of South Sulawesi, ed. Druce, S. C. International Journal of Asia Pacific Studies 12 (Supp. 1): 53-72, http://dx.doi.org/10.21315/ijaps2016.12.s1.4.

Macknight, C.C. and Mukhlis Paeni. n. d. The chronicle of Boné. Unpublished manuscript. 
McWilliam, A. 2009. Trunk and tip in West Timor: Precedence in a botanical idiom. In Precedence: Social differentiation in the Austronesian world, ed. Vischer, M. P., 111-132. Canberra: ANU E Press.

Millar, S. B. 1989. Bugis weddings: Rituals of social location in modern Indonesia. Berkeley: Center for South and Southeast Asia Studies, University of California.

Miller, C. 2016. A Gujarati origin for scripts of Sumatra, Sulawesi and the Philippines. Proceedings of Berkeley Linguistics Society 36. Forthcoming.

Niemann, G. K. 1883. Geschiedenis van Tanette. Boeginesche tekst met aanteekeningen. 's-Gravenhage: M. Nijhoff.

Noorduyn, J. 1955. Een achttiende-eeuwse kroniek van Wadjo': Buginese historiography. 's-Gravenhage: H. L. Smits.

Omar, R. 2003. The history of Boné A. D. 1775-1795: The diary of Sultan Ahmad as-Saleh Syamsuddin. PhD diss., University of Hull, United Kingdom.

Ottino, P. 1982. Myth and history: The Malagasy "Andriambahoaka" and the Indonesian legacy. History in Africa 9: 221-250.

Pelras, Ch. 1981. Célèbes-sud avant l'Islam selon les premiers témoignages étrangers. Archipel 21 (1): 153-184.

Quirino, C. (ed). 1973. Doctrina christiana en lengua Española y tagala. Manila: National Historical Commission.

Rafael, V. 1988. Contracting colonialism: Translation and Christian conversion in Tagalog society under early Spanish rule. Durham: Duke University Press.

Ras, J. J. 1968. Hikajat Bandjar: A study in Malay historiography. The Hague: M. Nijhoff.

Salim, M. ed. 1985. Lontarak Akkarungeng Luwu. Ujung Pandang: Pemerintah Daerah Tingkat I Sulawesi Selatan.

Sather, C. 1996. All threads are white: Iban egalitarianism reconsidered. In Origins, ancestry and alliance, eds. Fox, J. J. and Sather, C., 73-112. Canberra: ANU Press.

Silva, N. 2009. Nā hulu kupuna: To honor our intellectual ancestors. Biography 32 (1): 43-54.

Vansina, J. 1985. Oral tradition as history. Oxford: Currey.

Wellen, K. 2014. The open door: Early modern Wajorese statecraft and diaspora. DeKalb, Illinois: Northern Illinois University Press.

Zainal Abidin, A. 1985. Wajo' pada abad XV-XVI: Suatu penggalian sejarah terpendam Sulawesi Selatan dari Lontara'. Bandung: Penerbit Alumni. 


\section{Manuscript Sources}

H1514 Collectie Jacobus Noorduyn, KITLV Archives, University of Leiden Library.

MAK Old catalogue of the Bugis and Makasar manuscript collection of the Yayasan Kebudayaan Sulawesi Selatan dan Tenggara, Ujung Pandang.

NBG Bugis and Makasar manuscript collection of the Nederlands Bijbelgenootschap, University of Leiden Library.

LSW Lontaraq Sukuna Wajoq. Proyek Naskah Unhas No.01/MKH/1/Unhas UP Rol 73, No. 1-12. 